\title{
Forfatteren Hother Tolderlund.
}

\author{
Af August F. Schmidt.
}

I den Litteratur, der forefindes om Treårskrigen og om sidslesvigsk Folkeliv i 1850 'erne. indtager Hother Tolderlunds Boger en ret smuk Plads, hvad denne Afhandling antagelig vil vise.

Hother Hakon Viggo Tolderlund blev født 2. December 1820 i Naksk ov. Hans Forældre var Proviantforvalter Jørgen Tolderlund (døbt i Odense 4/1 1778, død 22/8 1845) og Hustru Christiane Sofie v. Flindt, født Tolderlund (f. 9/11 1784, d. 31/8 1835). Da Hother Tolderlund var fire År gammel, kom han til Sjælland, hvor Faderen fik Ansættelse som Godsforvalter ved de Scheel-Plessenske Godser Saltø og Harrested. I Godsforvalterboligen på Saltø ved Næstved voksede Hother Tolderlund op. I sit 13. Ar blev han sat i det v. Westenske Institut i København. Fra denne Læreanstalt blev han dimitteret til Universitetet i 1838. Til Studentereksamen nævnte År erholdt han 2. Karakter. En Sygdom, som havde oudvikJet sig under hans Opvækst, afbrød hans Studeringer. Efter en længere Tids Ophold på Landet kunde han i 1841 underkaste sig den philologisk-philosofiske Eksamen (haud. ill.), hrorefter han begyndte at studere Jura. Heri afbrødes han også af Sygdom og kunde først optage sine Studier igen i 1844. Han helligede sig nu Lægevidenskaben, som han var optaget af de følgende fire År, indtil han i 1848 afbrød dette Studium for at blive Underlæge ved Armeen, en Stilling, han godt kunde bestride, selv om han ikke havde taget medicinsk Embedseksamen. Han kom til at deltage i flere Træfninger i 1848 og 1849. Sine største Oplevelser havde han dog i 1850 under Slaget ved is ted, hvor han ved Oberstløjtnant Henckells Bataillon var med til at storme Stolk. Senere var han som eneste Lage til Stede ved Frederiksstads mindeværdige Bombardement 1.-5. Okto- 
ber 1850. Forplejningen af de sårede i Byen var ene betroet ham. Som Påskønelse for sin dygtige Færd i disse Dage blev han Dagen efter Bombardementets Ophør, 6. Oktober, udnævnt til Ridder af Danebroge.

Efter Fredsslutningen blev han stationeret forskellige Steder i Sønderjylland, fra 1852 som Militærlæge på Gottor p Slot, en Stilling, han først forlod ved Dannevirkes Romning den 5. Februar 1864. I den sidste Krig forrettede han Tjeneste på Lasaretterne i Augustenborg og Odense og ansattes derefter ved 20. Infanteri-Bataillon samt ved Crarnisonssygehuset i \& rhu s 14/3 (fra 20/4) 1865. I sidstnævnte By oprettede han i 1867 et Institut for medicinsk og orthopædisk Grmnastik. I 1868 fik han Jus practicandi (dog ikke som Fødselshjælper), men allerede i 1870 flyttede han til $\mathrm{K} ø \mathrm{~b}$ enhavn, hvor han nu helt ofrede sig for sit Forfatterskab.

Som 21-årig debuterede Hother 'Tolderlund med en nu glemt Samling "Lyriske Digte" (1841), som han udgav under Pseudonymet Vig g o L u uld. Senere, da der rigtig kom Gang i hans Skribentvirksomhed, offentliggjorde han mange af sine Arbejder under Forfattermærket D r. H.

Treårskrig e n var den store Oplevelse i Hother Tolderlunds Liv. Hans Skildringer fra denne Krig hører derfor ogsä til hans bedste litterære Frembringelser. Adskillige af dem er nedskrevet under selve Felttoget, hvorfor de har mere Frisklied og Flugt over sig end Hovedparten af hans øvrige Produktion. Tolderlunds bedste Stỵke i det hele taget er således uden Tvivl Brevfragmentet "I et nyt Quarter" (Skizzer 1855), hvor han morsomt fortæller om sine angelske Vartsfolk, der af lutter Venlighed ikke lod ham være ene noget Øjeblik. Bortset fra Digtsamlingen 1841 var Tolderlunds forste Bog det i 185.1 udkomne Arbejde: "Fortællinger fra Felten«. Det indledes med seks Afsnit "Erindringer fra 1850«. Først fortæller han underholdende om Marchen fra Als 15. og 16. Juli 1850. Man 
fár heri et ret levende Indtryk af den ikke modløse danske Hærs Tur sydpå forbi Flensborg og ned gennem det vestlige Angel, hvis landskabelige Skønhed, Tolderlund berømmer. I næste Kapitel hører vi så om Istedslaget 25/7 1850. Det er lykkedes Forfatteren at gengive en Del af Optrinnene og Kamptummelen (S. 22-28) temmelig virkningsfuldt, hvorfor det nok kan lønne sig at stifte Bekendtskab med den unge Lages Krigsoplevelser under det største Slag, der er udkæmpet på dansk Jord. $\left.{ }^{1}\right)$ Ikke mindst den morderiske Kamp i Stolk er der anskuelige Oplysninger om, endskønt Tolderlund ellers bedst formår at gengive Felttogets mere fredelige Oplevelser, hvad bl. a. Afsnittet "Bivouak og Forpost« viser. Slaget ved Isted gjorde den danske Hær til Herre over Sønderjylland med Undtagelse af de allersydligste Egne. Derfor blev betydelige Troppestyrker heordrede ned til Egnen ved Ek er n førde. Her lå Hæren i Jelte i længere Tid. Det kedsommelige Ophold her fortæller Hother Tolderlund godt om. Det er også vardifuldt at.Jæse halls Skildring af Byen S lesvig i Krigssommeren 1850, selv om man må foretrække Beretningen om Frederiks s a d og denne Bys Bombardement. Efter nogle historiske og topografiske Oplysninger meddeler Tolderlund sine Indtryk og Oplevelser fra den belejrede By. Det er mest Stadens Indbyggere ag deres Adfærd i den vanskelige Tid, der har hans Interesse. Cberst Hans Helgesen nævnes ikke med et Ord. Om Marsken og Husum er der også et Afsnit i "Fortallinger fra Felten “. ${ }^{2}$ ) Marsken kedlede Tolderlund, og Husum fandt han var en styg By. Derimod synes han naturligvis godt om sønderborg, hvor han en Tid lå indkvarteret. I Skitsen

1) En litterær Skildring, der også omtaler Kampene ved Stolk, findes i Henrik Scharlings Roman fra Trearskrigen: »Uffe Hjælms og Palle Løves Bedrifter' II (1866), 428-444. Præget af en Pealisme, der er ret usædvanlig i Erindringer fra Treårskrigen, er Fr. Hammerichs Fremstilling af sine Oplevelser under Istedslaget (se Fr. Hammerich: Et Levnedsløb I-II [1882], 108-114).

$\left.{ }^{2}\right)$ Flere Afsnit af denne Bog findes optrykt i "Folkelæsning", 3. Hefte (1867), 51-76. I »Folkelæsning 2 . Hefte (1867), 91--101 fincles en god lille Skildring af den tyske Skoleundervisning i Mellemsiesvigs rlanske Egne (af en Mellemslesviger). 
"Udsigt fra min Værts Have« er der Småtræk fra denne Stads Borgerliv, som han fik Lejlighed til at iagttage. I "Depotser* geanten«, "Marketentersken" og "Tambourens Giftermaal " har 'Tolderlund med et skarpt Blik for Pudsigheder og naiv Optræden hos "Militaire" af lavere Grader fortalt formøjelige Trak fra Hæren på Feltfod.

I Tidsskriftet »Nord og Syd « 1851, 269-303 er det Erindringer om Vinterlivet $1850-51$, Tolderlund offentliggør. Under Skildringen af Baraklivet i Sydslesvig finder han Anledning: til at udtale sin Beundring for de danske Soldater, for den Tálmodighed, hvormed de udholdt et Vinterfelttogs Strabadiser", og det gode Lune, som dette Livs dræbende Ensformighed og Kedsommelighed ikke kunde berøve dem.

Dr. H.'s næste Bog: "Skizzer« (1855) har også Bidrag om Krigen 1848-50. I et Indledningskapitel om Angel og Angelboexne giver Forfatteren en smuk Skildring af det frodige angelske Landskab, som han betragter under en Koretur igennem de Egne, hvor han et Årstid tidligere var til Fords, men da som Lage ved Hæren. Fornøjeligt er det her at læse om et Soldaterbal en Skærisommerdag, da Angelboerne holdt en Landsbyfest, medens - som tidligere navnt - Beretningen om det nye Kvarter særlig er vellykket.

Om Treårskrigen findes der også Oplysninger i Tolderlunds bedste Fortælling, Landsbyhistorien "Stille Vand" (Fortællinger, 2. Række 1863). Heri har han udnyttet af sin Viden fra Frederiksstads Belejring og Kampene ved denne By. Hovedhandlingen i "Stille Vand« er ellers henlagt til Sydsjælland. Endelig kan i denne Sammenhæng nævnes, at Tolderlund i Illustreret Tidende I (1859-60), S. 4-5 har offentliggjort en livlig Skildring af Kongerevuen 20/9. 1859 ved Flensborg, hvor der da var mange Soldater samlede, - o og at han i Fortællingen "Niels Rytter" (i Bogen Fra Syd og Nord 1876) har Optrin fra Krigen med England 1807-14. ${ }^{1}$ )

1) Fortællingen "Blomme« (Hjemmefra 1873) indeholder Oplys- . ninger om Rekrutmánederne på en Kaserne i Fredstid. 
Det andet Område af Hother Tolderlunds Forfatterskab, der endnu har Krav på Interesse, er hans Meddelelser om t o p ografiske og kulturhistoriske Emner. Indenfor denne Genre er hans bedste Bidrag at finde i Bogen: Skizzer (1855). Heri har han i »Frieriet«, på Grundlag af lagttagelser under Felttoget i An g e 1 1850, givet en både kulturhistorisk og psykologisk værdifuld Skildring af et $\mathrm{F}$ ri e r i i en velhavende Bondegård. Man får her en Del at vide om Levemåden og om de forskellige Personers Optræden ved sădan en højtidelig Anledning, hvor adskilligt flere end de to særligt implicerede var til Stede og fremkom med Udtalelser. - Et B ry ll u p har Tolderlund også givet en god Fremstilling af (Skizzer, 108-121), vist ikke fra Angel, men antagelig fra en Landsby på Sliens Sydside, idet der omtales Skikke, som fortrinsvis er af trsk Oprindelse, således »Polteraabend« eller »Brutlagaabend«, en Lystighed i Bryllupshuset Aftenen før selve Brylluppet. Pulteraftenen fandt der en Del støjende Løjer Sted, bl. a. blev som en Nytårsaften - Potter slået på Dørene og Bøsser afskudte. Endvidere var det Skik, at en Pige trådte ind og fremsagde et plattysk Polterabenddigt (hvoraf Tolderlund meddeler en Oversattelse bag i Bogen), hvorefter hun overrakte Brudeparret Gaver. "Pulteravden«-Skikken er nu nået så langt Nord på, at man i St or e S o l t Sogn i Nordvestangel kender bảde demne tyske Skik så vel som den danske Bryllupstradition, Fredags-Søndagsbryllupper. ${ }^{1}$ ) Bryllupsdagen i Landsbyen ved Slien var naturligvis en betydelig Fest. Mad og Drikke var der rigeligt af, Dansen gik godt Natten igennem, og unge Par i Byell talte om, hvor prægtigt det skulde gå til, når de selv skulde holde Bryllup. Selv om Tolderlunds Frieri- og Bryllupsskildringer har et skønlitterært Anlæg, indeholder de, som man vil forstå, dog Enkeltheder af folkloristisk Værdi. De bør

1) Fra Dansk Folkemindesamling VI (1938), udg. af Hans Ellckilde, Optegnelser af Andreas Lorenzen fra 1931. Jfr. Tolderlund i Folkekalender for Danmark 1858, 109-118, hvor et Bryllup i Ostenfeldegnen omtales. Bedst er dog her Tolderlunds Skildring af en li e gravels e i Ostenfeld. 
læses i Sammenhæng med H. F. F e il b ergs Bryllupsafsnit i Fra Heden (1920), 128-135 (V a l s b ol - S t. V i - F jold e) og Andreas Lorenzens Optegnelse om Bryllup i Havet of t Sogn i Vestangel (Fra Dansk Folkemindesamling VI, 149-151).

Hother Tolderlund har også leveret Bidrag til Oplysning om Byggeskikkene i Mellem- og Sydslesvig. Under sit Ophold på Gottorp Slot fik han Stunder til at gore sig bekendt med Slesvigegnens Landsbyer. Han er på sine Udflugter kommet i sydlig Retning og har fået Lejlighed til at studere. det s a ch hiske Hus, saaledes som det i modificeret Form fremtræder i Sydslesvig. I "Skizzer", 103-107 har han meddelt en ret grundig og instruktiv Fremstilling af sâdan et Hus' Indretning. I Kapitlet om Angel og Angelboerne giver Tolderlund (S. 9) en Omtale af Byggemåden i Angel. Gårdene dér »ligner Gaardene i Nordslesvig og paa Als«. De »bestaar af en lang Bygning med en Port paa Midten og som oftest en lille Sidefløi, der danner en Vinkel med Hovedbygningen .... bladet« for 1861, Nr. 42 resumerer Tolderlund sine Iagttagelser over Bygningsskikkene i vort Grænseland.

Det er værd at notere, at den lægeuddannede Skribent er en af de første, der har skrevet om et så etnologisk vigtigt Emne som dell danske og den sachsiske Bygningsmåde og om dennes T'ilsynekomst i Landsbyerne Nord og Syd for Slien. $\left.{ }^{1}\right)$ En meget stor Litteratur er om dette Spørgsmål fremkommet både

1) Her må det ikke glemmes, at Dialektforskeren F o l m e r D y r I u n d (18?6-1917), (ler var med i Treårskrigen, også har skrevet om clen sydslesvigske Byggeskik. Han lå en Tid indkvarteret i Egnen lige Nord for Dannevirke, i Ellingsted, Hollingsted $\mathrm{m}$. fl. Byer. Den dér herskende Bygningsmåde fangede hans Interesse. Efter Hjemkomsten udgav han et lille Skrift: $" O \mathrm{~m}$ B y g $\mathrm{n}$ ing $\mathrm{s}$ ma aden pa den syds lesvigske Land ry g“ (Holbæk 1853). Heri beskrives (let "nedersaksiske« Hus (med Hovedindgangen i Gavlenden), som det forefandtes Nord for Dannevirke. Ved at betragte Stednavnene kom byrlund til det Resultat, at denne Bygningsmade er en tysk Kile, (ler er drevet ind i oprindelig dansk Land. I Forordet til Bogen giver Dyrlund et levende Indtryk af Treårskrigens Idyl (jfr. K r i sten Møllers Biografi af F. Dyrlund i "Fra Rask til Wimmer» $193 \%, 64)$. 
på Dansk og Tysk, hvad man bl. a. kan få et stærkt Indtryk af ved at læse E rnst S ch l e e's bibliografiske Oversigt') over landsbybygningernes Historie og Arkitektur i Sønderjylland. Ernst Schlee anfører også en hel Del dansk Litteratur om Bønderbygninger, bl. a. Cla u s Eskildsens Dansk Grænselære (1936), hvori man nu kan finde de bedst mulige Oplysninger om Græ $\mathrm{n}$ s e n mellem dansk og sachsisk Brgningsskik.

I Angel var førhen det største Marked: "B rarup Ug e«, der holdtes i Landsbyen B r a r up (Slis Herred), hvor der har været en hellig Kilde. Det er altså et Kildemarked, vi her finder knyttet til Brarup. Markedet wholdtes Tirsdagen, Onsdagen og Torsdagen efter Jacobi«, og den dermed forbundue Kirkemesse holdtes Sct. Jacobs Dag den 25. Juli. Markedet var en stor Folkefest for hole Angel, hvad vi får et levende Indtryk af ved at læse Hother Tolderlunds Skildring af det $\mathbf{i}$ "Skizzer" (1855), 38-46. Tolderlund har selv overværet Brarup Marked. derfor har det været ham muligt at give sin livfulde og indholdsrige Fremstilling af denne Folkefest. Hans »Brarup Marked" hører ikke til de ringeste i den Række af skønlitterære Bidrag, der i vor Litteratur forefindes om de gamle, nu forsvundne Kildemarkeders Historie og Folkeliv. ${ }^{2}$ ) Brarup Marked stod i Flor til hen imod 1914. ${ }^{3}$ )

Til de gamle Arbejdsgilder hørte Brydningen af Hørren og Hørgarnets (og Uldgarnets) Henbringelse til Væveren. Ved Brydningen skulde Hørren tørres over en rask Ild $\mathrm{i}$ en Brydegrav eller Brødekule. Hørbrydningen samlede adskillige Arbejdsfolk, der havde travlt Dagen lang ved Brydegraven udenfor Landsbyen. Under dette Arbejde gik S11akken lystig, og efter endt Dagsgerning samledes Folkene til et

1) Zeitschrift der Gesellschaft für Schleswiø-Holsteinische Geschichte, Bind 66 (1938), 347-387.

2) August F. Schmidt: Danmarks Helligkilder (1926), 15\%. Sønderjydske Aarbøger 1926, 127. Hejmdal 20/5 1926.

3) Fra Dansk Folkemindesamling VI (1938), 146 (Ellekilde og Andr. Lorenzen). - I "Stoplidt" (Fortællinger 1860) har Tolderlund skrevet om et Efterårsmarked $i$ en Købstad, vistnok Nastved. I "Sent mødt" (Hjemmefra 1873) findes ogsä en - sjællanılsk Markedsskildring. 
lille Bry degil de, hvor der vankede et godt Traktement. Arbejdet i Brydegraven har Hother Tolderlund set en skøn Efterårsdag i en sydslesvigsk Landsby. Det interessante Indtryk af et sådant særegent Stykke Bondearbejde har han så snildeligt fundet Anvendelse for $\mathrm{i}$ sin Fortwlling: "Synsmandens F'ibe" (Fortællinger 1860, 158-59), hvori der også er Oplỵsninger om det gammeldags $H ø s$ t a $r$ b e j de. Hvad sidstnæunte Skildring angår, så er det mere Stemningen fra Høstmarken, det har været Forfatterens Hensigt at give, end Meddelelser af konkrete Enkeltheder, som kunde have indeholdt onskelige Kundskaber om sydslesvigske Høstskikke, hvorom der nu forefindes Arbejder af Arkivar $\mathrm{Hans}$ Ellekilde.) I ${ }^{1}$ En Tour til Væveren“ (Fortællinger 1860, 111-120) læser man om nogle Herregårdsbørns store Forventning den Dag, de måtte køre med deres Moder og Husjomfruen til Væveren med Garn. Turen var en hel Oplevelse for Børnene, der hos Væveren fik Kaffe sammen med de voksne; "thi Herregaardsfolkene maae altid drikke Kaffe, naar de satter Garn i Væv, men Brød føre de selv med«. De førte vist endnu flere Fødevarer med til Væveren; men da disse var indhyllet $i$ et Klæale, kunde Drengene ikke se hvormeget og af hvad Slags. Efter Kaffedrikningen lab Drengene ud i Skoven, indtil de skulde hjem, så man får ikke mere at høre om Vrevearbejde et.c. i Fortallingen, hvis Handling lige så godt kan have fundet Sted i A'ngel som i Sirdsjælland, da Vævergildet holdtes ligedan i Danmarks forskellige Egne.

I "Brudetræet« (Fortællinger 1860, 185) omtaler Tolderlund et $\mathrm{Humleg}$ il de i ell sydslesvigsk Landsby. Da man kun har ganske få Optegnelser om dette Arbejdsgilde uden for Fyn, skømner man på, at der også foreligger en Oplysuning om Afpilning af Humleknopper fra vort Folks sydligste Egne. Tolderlunds Fremstilling er i Overensstemmelse med de virkelige Begivenheder, man ser Arbejdsflokken for sig i Dielen, og man passim.

1) Se Henvisninger i Fra Dansk Folkemindesamling VI, 6 og 
hører deres Snak og Latter. I øvrigt indeholder "Brudetræet" nydelige Genrebilleder fra Landsbyen; Småskikke, Børns Leg (Efterligning af et Bryllupsgilde), Remser, Kukmandstale o. $\mathrm{s}$. fr. liver op i Fortællingen, der ligesom "Mølleslumpen" (Fortællinger 1860) er af mere end ren litterær Værdi. I »Mølleslumpen“ hører man om Skeltrætte, Byhyrde, Fattigkonen Trutmaren, der ansås for at være en Heks, Børneremser, Småkårsfolk og Storbønder $m$. v., så det er nok ikke med Urette, at denne Fortælling sammen med "Synsmandens Pibe" af C. R os e n berg i Illustreret Tidende I, S. 107 er blevet sammenlignet med Værker af den hollandske Skole, idet de er udarbejdede med så megen Omhu, at alle Detailler står Læseren klart for $\varnothing j e$, og Indtrykket af et landligt Stillebeu bevares i Erindringen længe efter Tilegnelsen af disse Skildringer af sydslesvigsk Almueliv.

I et Par mindre Skriftstykker har Hother Tolderlund givet Naturstemninger fra og historiske Oplysninger om Sli e $n$ og G ot t o r p S l ot (Skizzer 1855, 89-102), sidstnævnte Opsats er angivet som forfattet i 1853 . Det er naturligvis let forståeligt, at en skriveøvet Mand som Tolderlund har fået Lyst til at meddele Læseverdenen journalistiske Indtryk af den skønne og historisk interessante Egn, han var kommet til at bo i efter Treårskrigens Slutning. Da han ikke af Drift var historisk Forsker, har han ikke leveret dỵbtgående Undersøgelser om Slesvigegnens Historie således som de to Lærere ved Slesvig Domskole J. N. S c h midt (Lærer der 1851-52) og C. C. Lorenzen (Adjunkt i Slesvig 1856-1861.) $)^{1}$ ) Tolderlund har antagelig ikke kendt nogen af de to Mænd personlig; Schmidts tidlige Død kunde $\mathrm{i}$ givet Fald ikke have fået et Bekendtskab til at vare længere end nogle Maaneder. Det er imidlertid ret ejendommeligt at tænke på, at tre af Sønderjyllands flittigste Skribenter i 1850 'erne omtrent samtidig havde deres Gerning i den berømte gamle By ved Slien.

$*$

1) Søndlerjydlske Aarboger 193\%, 112, 211. 
I 1852 foretog Hother Tolderlund en Rejse ud til Vests lesvig og Vesterhavsøerne i den sydlige Del af Vadelavet. Hans Rejsebeskrivelse herude fra er ikke ilde.) Han fortæller (i Skizzer 1855, 49-85) på sin jævne og hyggelige Facon om Postillonsturen tværs over Sønderjylland fra Fle n s borg over $\mathrm{L} æ \mathrm{k}$ og $\mathrm{N}$ i bøl til D a g e bøl, hvorfra der er Overfartssted til $F ø h r^{2}$ ), hvor han straks aflagde Flakken $W y k$ et Besøg. Efter Omtalen af Wyk fremkommer Tolderlund med en Del Oplysninger om Føhrs Historie og Topografi, hvorefter han fortæller om Bønder og Søfolk, om Kvinderne, der må forrette Markarbejdet, medens Mændene er borte på Havene - mest som Hvalfangere i Nordhavet - ligesom han med vågen Sans beskriver Nationaldragten på (đen. ${ }^{3}$ ) Under Omtalen af Næringslivet på Føhr får Forfatteren Lejlighed til at fortælle om Jor‘lens Dyrkning og om de hjemvendte Hvalfangere, der har indhegnet deres Haver med store Hvalbarder, medens man inde i Husene finder adskillige Vidnesbyrd om Mændenes Rejser til fjerne Egne af Kloden. Trods Øernes Fattigdom længes de søfarende Mænd dog altid tilbage til deres Hjemstavn, hvor de i j)eskedne Kår hygger sig på de gamle Dage.4)

A m ru m har Tolderlund også en smuk Skildring af; ikke mindst denne $\varnothing$ 's Sandbjerge har gjort Indtryk på den Tilrej-

1) Man laser dem gerne og afholder sig fra Sidehlik til H. C. A nre rsens "Mit Livs Eventyr I (Udg. 1926), 273-281 og "De to Baronesser" (med Oplysninger fra Fohr). St. St. B I i c her har ligeledes skildret Halligerne og Føhr (»Vestlig Profil af den Cimbriske Halvo 1839), se St. Blichers Samlede Varker, Bind 23 (1929), 91-97. H. (.. Anclersens Oplevelser stammer fra hans Rejse i 1845 i Christian VIIIs Selskab til Føhr og Halligerne, der af Eventyrdigteren træffencle kaldes "Gr"essuner i Havet «.

2) I Tilslutning til Kor'etursskildringen af Marsken kan navnes Tolderlunds nyttige Artikel i Illustreret Tidiende I (1859-60), S. 152 om den sønderjydske Marsk.

*) Jfr. hermed Tolderlunds Ontale af Folkerlmaten i os tenf e l d (Folkekalender for Danmark 18:8, 111-112). Sammesterls 1861, 42-43 er Ostenfelddragten ogsaa omtalt i en illustreret Artikel. Klæleflragten i Angel er omtalt i "Skizzer", S. 9.

4) Trlførlige Oplysninger om alt herhenhørende kan man nu finde i Wanda Oes a u's store og smukt illustrerede Væerk: SchleswigHolsteins Grönlandsfahrt auf Walfischfang und Robbenschlag vom 17.-19. Jahrhundert (1937). Jfr. Cræensevagten 1938, 149-50. 
sende. Han fortæller derfra et godt Sagn om Klitten Olu f sd y n e (S. 71) og meddeler Oplysininger af folkepsykologisk Værdi vedrørende Folkets Syn på Strandinger og farefulde Situationer. - Halliger n e giver han forskellige Oplysninger om især i naturhistorisk og topografisk Henseende. Nævnes må her særlig hans Omtale af 0 lands gamle Kirkegård. ${ }^{1}$ ) Fra Halligerne vendte Tolderlund tilbage til Føhr, som han får set det meste af, hvorfor hans Turistiagttagelser herfra ikke er uden Værdi. Bedst er dog her hans Omtale af et Besøg ved en F u glekøje, hvor Fuglefangstmanden Jan Johannsen giver ham god Vejledning $i$ den på Vesterhavsøerne anvencite ret sinclrige Måde at fange vilde Svømmefugle på. Øboerne har laert Fangstmetoden fra Holland. Til sidst fortæller han et og anclet om Badelivet på Føhr og om de Forlystelser, der var for Badegæsterne at deltage i Aar 1852. Her nævnes forst Jagtpartier, Ldflugter til Halligerne og lange Spadsereture, weller man ligger og strækker sig, lader Bølgerne kysse sine Fødder og Øinene tankeløst svæve hen over Havet, der blinker i Solen, som regnede Sølvdraaber ned paa dets mørkeblaae Flade. Isandhed, det er kun tarvelige Forlystelser. Og dog flyve Dagene altfor hurtigt forbi; naar man skal forlade den venlige By [Wyk], seer man med Forbauselse, at en tre, fire Uger ere gaaede hen, siden man kom der; man veed ikke hvorledes; man pakker sin Kuffert og sukker: "Allerede« - man befinder sig godt paa Føhr, man driver saa mageløst. $\left.\ll^{2}\right)$

Dermed forlader Tolderlund Vesterhavsøerne. Sil d besogte han ikke, men derfra er vi også så heldige at besidde J o r-

1) I Folkekalender for Dammark 185\%, 30-33 har Tolderlund offentliggjort en Skildring af den lille $\varnothing \mathrm{B}$ e $\mathrm{n}$ s h a $11 \mathrm{ig}$, hvor der i sin 'Tirl boede et enligt $\mathbf{E g t e p a r}$, der fik Idyllen odelagt, la Manilen i Smur tomte et Anker Vin, som en venlig Bølge havde skyllet i Lanı. Herover blev Konen naturligvis vred. "Beens Hallig er optrykt i Tolderlunds "Udvalgte Fortællinger" (1916).

2) En hel anden Stemning fra Vesterbavsøerne ha V a I d e u a $\mathrm{r}^{\circ}$ Rorda m givet et Indtryk af i sine Rejseoplevelser blandt Norrlfiserne verl Verdenskrigens Irlbrud 1914 (se Rarlam: JIjomme i sonderjylland, 2. Oplag 1919, 82 ff.). 
ge e B. Høy ers Rejseskildring fra $\left.1908,{ }^{1}\right)$ og den står fuldt rá Højde med, hvad "Dr. H.« kunde have skrevet om demne lange Ø's Natur og Historie. $\left.{ }^{2}\right)$

\section{*}

Vi har nu omtalt alt det væsentlige af Hother Tolderlunds Forfatterskab, hvor det er $\mathrm{s} ø \mathrm{nderjydske} \mathrm{Emner} \mathrm{eller} \mathrm{Be-}$ givenheder knyttet til Sønderjylland, der optager Hovedpladsen. Derudover har han skrevet endnu en Del Bøger og Artikler, sáledes »Fortællinger", 2. Række (1863), "Fortællinger og Skildringer« (1868), »Hjemmefra (1873) og »Fra Syd og Nord« (1876). Da Tolderlund var en temmelig berejst Mand, omfatter en ikke uvæsentlig Del af hans Forfatterskab Rejseoplevelser og Fortællinger med Motiv hentet fra fremmede Lande. Dette gælder sáledes Fortællinger i Bøgerne "Fortællinger" (1860) og "Fra Syd og Nord« (1876), der ikke indeholder direkte Rejseoplevelser, således som hans Bøger "Rejsebilleder" (1855) og "Billeder fra Orienten « (1875) gør det. $\left.{ }^{3}\right)$

I 1854 foretog han en Fodrejse i Harzen, besøgte $1857 \mathrm{og}$ 1863 for sit Helbreds Skyld Franzenbad i Bøhmen og 1862 af samme Grund Vandkuranstalten ved Gadersberg og forbandt med disse Rejser Udflugter til adskillige Steder i Tyskland. I Sommeren 1865 foretog han en Rejse til Sverrig og i 1873-74 en Rejse til Orienten, hvorom hans fortræffelige Bog: "Billecler fra Orienten “ indeholder Oplysninger. ${ }^{4}$ ) Også til Frankrig og Schweiz foretog Tolderlund Rejser.5) Det var nok ikke alene for sit Helbreds Skyld, han rejste meget; også for at adsprede

1) Se Sønderjydske Aarbøger 1938, 55, 60.

2) Om Vesterhavsøerne, deres Natur og Historie m. v. se N. H. Jacobsen: Skibsfarten i det danske Vadehav (1937).

$\left.{ }^{3}\right)$ Af hans indenlandske Rejseoplevelser udenfor Sønderjylland fortjener at nævnes hans Rejseskildring: »Himmelbjerg og Bovbjerg" (Foltællinger og Skildringer, Ny Samling I, 1868).

4) Th. H. Erslew: Supplement til "Almindeligt Forfatter-Lexicon" III (1868), S. 447-49. L. Tolderlund-Hansen: Meddelelser om Slægten Tolrlerlund (1915), 9, 12, 43-44.

5) Glemmes må det ikke, at Hother Tolderlund jeverede en Mængde Oversattelser til forskellige Blade, bl. a. til „Fadrelandet «s Feuilleton. 
tunge og triste Tanker drog han ud. På sine æeldre Dage var han stærkt angreben af Melankoli, vistnok en Følge dels af en ulykkelig Ungdomskærlighed, der lod ham forblive ugift, dels af at han ikke syntes, han havde nået det Mål, han i sin Ungdom havde sat sig. $\mathrm{Ni}$ c ol a i B o g h omtaler Fother Tolderlund som en skattet Selskabsmand, en meget nobel og tiltalende Personlighed, hvis fine Dannelse, forenet med et elskværdigt og behageligt Væsen, afspejler sig i det Forfatterskab, han cfterlod sig. ${ }^{1}$ ) Som en ensom Mand døde han efter 8 Dages Sygeleje den 9. April 1880 i København. ${ }^{2}$ )

Hother Tolderlund nød i sin Samtid en vis Anseelse. Flere af hans Folkelivsskildringer var kendt af de fleste læsende Mennesker i vort Land, bl. a. Landsbyhistorien "Stille Vand «, cler blev optaget $i$ en Skolelæsebog, hvor nærv. Forf. som Barn første Gang stiftede Bekendtskab med »Dr. H.«. I denne Fortælling, der er skrevet $\mathrm{i}$ et godt Sprog, viser Tolderlund, at han besad god Iagttagelsesevne og ejedle et menneskekærligt Sind.

Tolderlund havde ingen kunstneriske Pretentioner, ligesom han ikke var i Besiddelse af noget dybt og omfangsrigt Skabertalent, men han havde gode Kompositionsevner og kunde fortælle med Lune og Smag. Hans nærmeste litterære Forbillede og åndelige beslægtede var Carl B e r n hard. Bedst er Tolderlund, hvor hans Karakterer er grebne ud af det virkelige Liv, som Tilfældet oftest er $\mathrm{i}$ hans sydslesvigske Arbejder (jfr. hermed hans Juleaftenshistorie "To Brødre", i Folkekalender for Danmark 1866, 37-66). Han havde et skarpt Øje for det ejendommelige og poetiske i Naturen og Menneskelivet, og man føler sig tit under Læsningen af hans Bøger underholdt på en berigende og værdifuld Måde. Fans humane Dannelse og Tankesæt virker velgørende på ligestemte Sind.

1) Dansk biografisk Lexikon XVII (1903), 429-31. Jfr. Oluf Friis i Dansk biografisk Håndleksikon III (1926), 590 merl Tolderlunds I'ortræt.

2) Berlingske Tidende 12/4 1880 (Nekrolog). 
Et smukt Uldtryk for Tolderlunds Evne til at omtale almindelige Oplevelser på findes i hans Fortælling: "Fra en Sommerreise« (Skizzer 1855, 126 ff.), hvor en Rejseskildring sætter Læseren $i$ en Stemning, der ikke er ulig den, man føler i sit Sind, når man læser F. C. S i b b ern $\mathbf{s}$ Beskrivelse af en Spadseretur i Fåborg en Sommermorgen (i Gabrieli s' Breve) ${ }^{1}$ ), men når denne Sammenligning er draget, må det ikke lades uomtalt, at Sibberns Kapitel i Gabrielis' Breve er et af de ypperste og tankerigeste Stykker Prosa, vor Litteratur besidder, medens 'Tolderlunds »Sommerreise« mangler Sibberns Dybde.

Tolderlund er nu en så godt som glemt Forfatter. Hans Bøger kan ikke længere regne med noget større Læsepublikum, dertil er de for lidt effektfulde. De indeholder kun Beretninger fra de "gode, gamle Dage«. Det var" derfor sikkert et økonomisk Vovestykke for J. L. Lybeckers Forlag i 1916 at udgive "Udvalgte Fortællinger" af Hother Tolderlund (ved A l e x a n d e r S chumach er). Man tør dog håbe, at Forlaget fik Glæde af sin fortjenstfulde Publikation, der indeholdt »en smagfuld og elskværdig Buket« af den gamle Skribents bedste Arbejder, nemlig Fortællingerne: Udsigt fra min Værts Have, Frieriet, Synsmandens Pibe, Beens Hallig, En Tur til Væveren, Svigerin.den, Stille Vand, En Kop Kaffe, Galocherne. De hører til den Litteraturgenre, der egnede sig så passende til Højtlæsning i Privathjem, men nu hører denne Form for Aftenunderholdning jo Fortiden til.

Da imidlertid Tolderlunds krigshistoriske og kulturhistoriske Skildringer fra Landet mellem Skelbækken og. Ejderen stadig kan gøre Gavn ved det Indhold af autentiske Oplysninger, de er forlenede med, er det formålstjenligt at henlede Opniærksomheden på dem, hvilket har fundet Sted på de foranstående Sider.

12./5. 1939.

A ugust F. Sch midt.

1) Gabrielis Breve, udg. af Poul T u x e $\mathrm{n}$ 1927, $164 \mathrm{ff}$. 